\title{
PROFILE OF AN INTENSIVE CARE NURSE IN DIFFERENT REGIONS OF BRAZIL
}

\author{
Renata Andrea Pietro Pereira Viana ${ }^{1}$, Mara Ambrosina de Oliveira Vargas², Maria Isabel Sampaio \\ Carmagnani ${ }^{3}$ Luiza Hiromi Tanaka ${ }^{4}$, Kely Regina da Luz ${ }^{5}$, Pablo Henrique Schmitt ${ }^{6}$
}

\begin{abstract}
${ }^{1}$ Ph.D. in Nursing by Escola Paulista de Enfermagem (EPE) at the Federal University of São Paulo (UNIFESP). Chief Nurse of the Intensive Care Unit at Hospital do Servidor Público Estadual de São Paulo (HSPE-SP). São Paulo, Brazil. E-mail: renata_pietro@yahoo.com.br

${ }^{2}$ Ph.D. in Philosophy in Nursing. Professor at the Nursing Graduate Program and Department at the Federal University of Santa Catarina (UFSC). Santa Catarina, Brazil. E-mail: mara@ccs.ufsc.br

${ }^{3}$ Ph.D. in Human Communication Disorders. Associate Professor and Researcher at the Nursing Graduate Program of EPE/ UNIFESP. São Paulo, Brazil. E-mail: carmagnani@unifesp.br

${ }^{4}$ Ph.D. in Nursing. Researcher at the Nursing Graduate Program of EPE/UNIFESP. São Paulo, Brazil. E-mail: simplesmenteluizinha@yahoo.com.br

${ }^{5}$ Master's Student in the at the Nursing Graduate Program of UFSC. Santa Catarina, Brazil. E-mail: kelydaluz@yahoo.com.br

${ }^{6}$ Nurse. MBA in Healthcare Auditing by the School of Management and Health Sciences. Rio Grande do Sul, Brazil. E-mail: enf.pablo@yahoo.com.br
\end{abstract}

\begin{abstract}
The aim of this quantitative study was to identify the socio-demographic and academic profile of intensive care registered nurses and participants of the events organized by the Department of Nursing of the Brazilian Association of Intensive Care Medicine. Data were collected by means of 400 questionnaires applied between January and July of 2010, however only 324 questionnaires were returned and 295 questionnaires were considered for the analysis. Data were analyzed with descriptive statistics resources with absolute relative frequency and simple mean, presented in tables. Results show the predominance of women, with specific graduate degrees. The skills and values highlighted include technical and scientific knowledge, and leadership. These professionals seek work in intensive care because of the high technological complexity. The study emphasized the existence of the professional profile required to work in the intensive care unit. The qualification of these professionals must prioritize the mastering of the technological language and the comprehensive and safe care.
\end{abstract}

DESCRIPTORS: Nursing. Intensive Care Units. Professional competence. Nursing research. Nursing education.

\section{PERFIL DO ENFERMEIRO DE TERAPIA INTENSIVA EM DIFERENTES REGIÕES DO BRASIL}

RESUMO: Pesquisa quantitativa cujo objetivo foi identificar o perfil sociodemográfico e acadêmico dos enfermeiros intensivistas associados e participantes de eventos promovidos pelo Departamento de Enfermagem da Associação de Medicina Intensiva Brasileira. Coleta de dados efetivada por meio da distribuição de 400 questionários, no período de janeiro a julho de 2010. Retornaram 324 questionários, e considerou-se para análise 295 questionários. Os dados foram analisados com recursos da estatística descritiva com a frequência absoluta relativa e a média simples, apresentados em tabelas. Os resultados evidenciam o predomínio do sexo feminino, com formação em curso de Pós-Graduação Lato Sensu específico na área. Dentre as competências, valoriza-se o conhecimento técnicocientífico e a liderança. Estes profissionais buscam atuar na terapia intensiva pela alta complexidade tecnológica. Admite-se a existência de um perfil profissional para trabalhar em unidade de terapia intensiva. A qualificação profissional deve priorizar o domínio da linguagem tecnológica e a assistência integral e segura.

DESCRITORES: Enfermagem. Unidades de Terapia Intensiva. Competência profissional. Pesquisa em enfermagem. Educação em enfermagem.

\section{PERFIL DEL ENFERMERO DE TERAPIA INTENSIVA EN DIFERENTES REGIONES DE BRASIL}

\begin{abstract}
RESUMEN: Investigación cuantitativa cuyo objetivo fue identificar el perfil sociodemográfico y académico de los enfermeros intensivistas asociados y participantes en eventos promovidos por el Departamento de Enfermería de la Asociación de Medicina Intensiva Brasileña. La recolección de datos se dio por medio de la distribución de 400 cuestionarios, en el período de enero a julio de 2010. Retornaron 324 cuestionarios y solo se consideraron para el análisis 295. Los datos fueron analizados con recursos de estadística descriptiva de frecuencia absoluta relativa y medias simples presentadas en tablas. Los resultados evidencian el predominio de sexo femenino, con formación de Post-Grado Lato Sensu, específico en el área. Dentro de las competencias se valorizan el conocimiento técnico científico y liderazgo. Estos profesionales buscan actuar en la terapia intensiva por la alta complejidad tecnológica. Se admite la existencia de un perfil profesional para trabajar en la unidad de terapia intensiva. La calificación profesional debe priorizar el dominio del lenguaje tecnológico y la asistencia integral y segura.
\end{abstract}

DESCRIPTORES: Enfermería. Unidad de Terapia Intensiva. Competencia profesional. Investigación en enfermería. Educación en enfermería.

Text Context Nursing, Florianópolis, 2014 Jan-Mar; 23(1): 151-9. 


\section{INTRODUCTION}

The Intensive Care Unit (ICU) is a place equipped with highly complex technology, an optimized context for the hospitalization of patients who are critically ill and need a professional team with specific competences. Therefore, the admission of expert nurses in intensive care and who have recognized skills and/or specific knowledge in this field is recommended for the activity in ICUs. ${ }^{1}$ Yet, in this environment called intensive care, these professionals need to recognize singularity, emotional, physical and psychological frailty in human beings, developing attitudes that enable them, while dealing with the disease process of the patient.

The quest for knowledge and the exchanging of experience in Brazilian intensive care occur mainly through meetings at events and scientific programs broadcast throughout the country and which provide reflections and collective constructions in ICUs. For such a condition, the Nursing Department at the Brazilian Association of Intensive Medicine (AMIB, as per its acronym in Portuguese), created in 1992, stands out in its national representation, mobilizing several lectures, conferences and activities to constantly update their members, who look out for scientific improvement and the development of professional skills. In partnership with AMIB, it is important to learn about the profile of the professional who currently works in intensive care in different regions of the country.

AMIB is a medical society that also aggregates other professionals in intensive care, among these, nurses, physiotherapists, psychologists, dentists and nutritionists. Currently, the largest non-medical department within the society is the Nursing Department, which has approximately 800 nurses, who, at the time of carrying out this research, counted on 625 member nurses throughout Brazil. Usually, professionals who become members seek a means for scientific update, through meetings, conferences, seminars, workshops, reunions and other activities that promote a spirit of unity, cordiality, contributing to the development of professionals in intensive care. Another goal is to stimulate national and international relations with similar associations, targeting the improvement of scientific and technical professionals in the area.

In this direction, other societies have been extending this partnership through departments. Among many examples, there are nurses par- ticipating in the Department of Nephrology at the Nephrology Society, the Multidisciplinary Society for Public Health, Nursing Department at the Brazilian Diabetes Society and the Nursing Department at the Brazilian Society of Hemodynamics and Interventionist Cardiology.

In 2010, the Department of Nursing at AMIB founded the Brazilian Association of Nursing in Intensive Care (ABENTI, as per its acronym in Portuguese). This conquest has increased the possibilities of activities hitherto undertaken. In other words, the first contest of Exams and Titles for Specialist Nurses in Intensive Care took place during the Brazilian Congress of Intensive Medicine at AMIB. This contest is held annually and counts on the support of the Federal Nursing Counsel and the Brazilian Nursing Association.

Finally, the motivation for this study focuses on the need to learn more about this nurse, who is associated with the nursing department of AMIB and participates in events organized by this department. Therefore, knowing the profile of nurses who work in intensive care proves to be relevant and pertinent due to the constant challenge that this professional is made to perform in an arena filled with fully utilized technology, which makes it important to search for the prevention of errors, adverse events and complications, besides the constant confrontation with the threshold between life and death, and a peculiar way of seeking to exercise humanized practices. ${ }^{2-4}$ In other words, it is up to nursing professionals to identify their own ideas regarding severely sick patients and establishing strategies for coping, aiming at appropriate and effective care that enables minimizing the suffering of all of those involved in the care process. Yet, in this context, knowing the profile of professionals subsidizes the adoption of strategies for developing continuing education programs in service and consequent professional training.

Skills generate results and these skills are closely linked to the professional profile. Therefore, it is pertinent to highlight a specific function or position, and the knowledge, skills and attitudes necessary to obtain good results. ${ }^{2-4}$ In this sense, the development of skills and abilities is considered to cope with changes, consistent with the trends in a globalized world where access to information is apparently universal and technological advances occur quickly in production. ${ }^{2}$

Thus, the development of this study aimed to identify the sociodemographic and academic profile of intensive care member nurses and 
participants in events organized by the Nursing Department of AMIB.

\section{METHOD}

A quantitative, exploratory and descriptive study developed with intensive care nurses who work in intensive care and attend events held by the Nursing Department of AMIB in 2010.

The research was planned in accordance with Resolution 196 from October 10, 1996, of the National Health Council, and submitted to the Research Ethics Committee (REC) of the Federal University of São Paulo. ${ }^{5}$ The REC issued the approval on October 9, 2009, under protocol n. $1426 / 09$. Data collection in the field of study was authorized by the AMIB and the participants were informed about the objective of the study, their guaranteed anonymity, and signed the Informed Consent Form (ICF) prior to data collection.

Participants took up research science upon registration at the event, as the questionnaire and two copies of the ICF were made available together with the scientific programming and ten minutes before the event started, the researcher presented on-stage guidelines for voluntary participation in the research, reinforcing the questionnaire and one copy of the ICF was returned at the interval of the event. At this stage, the questionnaire contained questions that sought to characterize the sociodemographic and academic-professional profile of nurses who attended the events in intensive care in different regions of Brazil.

All participating member nurses at the AMIB, who worked in intensive care, were approached, with a total distribution of 400 questionnaires. Exclusion criteria were applied to non-AMIB member nurses and participants of the event who did not work in intensive care. The research covered 114 professionals in the North, at a forum in the city of Manaus, in the Northeast, 80 nurses in the city of Recife, 86 professionals in the Midwest Region (Goiânia) and 120 professionals in the Southeast, with an event held in São Paulo. In the year of data collection, there were no events in the southern region of the country, justifying the absence of a sample.

The instrument consisted of open semistructured questions and was divided into two parts. The first part focused on questions with personal data and the second with questions assigned to learn the professional trajectory of the participant nurses, including questions with the following areas of development: 1) Characterization of the personal profile of nurses by: sex, age, marital status and children; 2) Characterization of academic-professional profile: professional qualification relating to undergraduate and graduate students; work regime and number of jobs; 3) Characterization of personal and institutional motivations of ICU capacity; 4) Competences that ICU nurses need to have or develop; and 5) Difficulties encountered in the development of continuing education activities in the ICU.

A pre-test was conducted with six intensive care nurses, but it was not included in the survey. There was no modification to the instrument. Data were grouped and analyzed with descriptive statistical resources, with absolute relative frequency and simple mean arithmetic, and presented in tables.

\section{RESULTS}

Of the 400 questionnaires distributed, 324 questionnaires were returned completed. Of these, 29 questionnaires were disregarded, because 16 were incomplete and did not bring the necessary information, and 13 questionnaires were completed by professionals who no longer worked in the field of intensive care and attended events to update knowledge. Thus, 295 questionnaires were considered for data analysis.

Table 1 - Socio-demographic profile of ICU nurses. São Paulo-SP, 2010

\begin{tabular}{llrr}
\hline Variables & & $\mathbf{n}$ & $\%$ \\
\hline \multirow{2}{*}{ Sex } & Male & 57 & 20 \\
& Female & 238 & 80 \\
& $20-29$ & 118 & 40 \\
Age & $30-39$ & 122 & 41 \\
& $40-49$ & 47 & 16 \\
& $50-59$ & 8 & 3 \\
\multirow{4}{*}{ Marital status } & Married & 159 & 54 \\
& Divorced & 114 & 38 \\
& Widowed & 21 & 7 \\
\multirow{3}{*}{ Children } & No children & 1 & 1 \\
& Have children & 173 & 59 \\
\hline
\end{tabular}


Table 1 shows a predominance of women $(80 \%)$, even though a contingent increase in men was perceived $(20 \%)$. The mean age of professionals between 30 and 39 years $(41 \%)$ prevailed, with these professionals being young, single and childless. Nevertheless, the percentage of married nurses and/or who have children is significant.

In table 2, the academic-professional profile considered in this research is presented, such as encompassing education, type of employment and number of jobs.

Table 2 - Academic-professional profile of Intensive Care Nurses. São Paulo-SP, 2010

\begin{tabular}{llrr}
\hline Variables & & n & $\%$ \\
\hline Undergraduate Pro- & Public university & 66 & 22 \\
gram & Private university & 229 & 78 \\
& Yes & 240 & 81 \\
Lato Sensu Graduate & No & 55 & 19 \\
Program & 14 & 5 \\
Stricto Sensu Graduate & Master's Degree & 1 & 0.3 \\
Program & Ph.D. & 8 & 3 \\
Undergraduate pro- & Yes & 287 & 97 \\
gram in another area & No & 131 & 44 \\
Technical Nursing & Yes & 164 & 56 \\
Course & No & 170 & 58 \\
& Contracted (CLT) & 60 & 20 \\
& Statutory employee & & \\
Employment & Public entrance & 63 & 21 \\
& examinees & 2 & 1 \\
& Others & 155 & 53 \\
& Only one & 140 & 47 \\
\hline Number of jobs & More than one & & \\
\hline & & &
\end{tabular}

Most professionals graduated from private universities (78\%). With regard to graduate training, $81 \%$ of professionals concluded Lato Sensu specializations. Professionals on a working regime with the CLT (Brazilian Labor Law Consolidation) and with one job are predominant.

The following table shows the necessary professional skills to work in intensive care, according to the study participants.
The respondents cited more than one skill, showing that the main ones highlighted by intensive care nurses to develop their roles with excellence are technical and scientific knowledge, followed by leadership and teamwork.

Table 3 - Professional skills necessary for nurses to work in intensive care. São Paulo-SP, 2010

\begin{tabular}{lc}
\hline Skills & $\mathbf{n}$ \\
\hline Technical knowledge & 177 \\
Scientific knowledge & 151 \\
Leadership & 113 \\
Knowing how to work in a team & 81 \\
Knowing how to manage & 52 \\
Holistic view of caring & 51 \\
Cognitive skills & 43
\end{tabular}

Showing decision-making abilities $\quad 42$

Humanization 40

Communication 30

Initiative and attitude 28

Interpersonal relationships 23

Commitment 22

Clinical reasoning $\quad 21$

Responsibility 20

Security 19

Being proactive 18

Being dynamic 17

Team coordination 16

Being ethical 9

Dedication and observation 9

Liking what you do 8

Emotional control 6

Knowing how to listen 5

Conducting research 4

Power of negotiation 3

Creativity 2

Vocation 1 
Among the motivations for working in the ICU, the nurses emphasized the aspect of working directly with the highly complex situation of critically ill patients and in an environment full of technology (75\%). Moreover, the high complexity is also evident when participants report: the power of action and execution; temperament and dynamic profile; satisfaction with the possibility of teaching and research, and the privilege of occupying a different status compared to nurses from other clinics.

Table 4 shows the difficulties encountered by nurses for the development of in-service education activities. In this case, it indicates that each participant can report some difficulty.

Table 4 - Difficulties encountered by nurses for the development of in-service educational activities in the intensive care environment. São Paulo-SP, 2010

\section{Difficulties \\ Lack of continuing education programs in the institution where he/she works \\ Lack of time for out of service professional quali- fication}

Tiredness and stress

Need to maintain more than one job

\section{DISCUSSION}

Being a woman, young and childless configures a possible relationship to be established based on the results of this study. This reality presents similar results to other study, whose theme was the stress of nurses in the ICU. ${ }^{6}$ In other words, in the investigation, $92 \%$ were female and $80 \%$ young people under 40 years of age. These data are further corroborated by the results reported by the Federal Nursing Council (COFEN, as per its acronym in Portuguese), which in 2010 accounted for 287,119 nurses, and of these, $88 \%$ were made up of women. As regards age, the COFEN survey indicates the prevalence of the age group between 26 and 35 years of age, which correspond to $44 \%$, and, in second place, with $22 \%, 36-45$ years age. ${ }^{7}$

The predominance of intensive care nurses graduated from private universities is confirmed in another study. ${ }^{8}$ In this sense, it reports a greater number of graduates from private institutions due to the increased number of private undergraduate courses in nursing. It also stresses that, in Brazil, there were 183 undergraduate nursing courses at the time of the study, with $40 \%$ being in public institutions and $60 \%$ in private ones. This number has grown $218 \%$ in a six-year period, reaching 582 courses, with $18 \%$ being federal and $82 \%$ private. $^{8}$

It is known that the growth of offers in higher education has primarily come from private institutions, but the supply of places in public institutions has increased significantly in recent years due to the expansion of federal public universities across the country. Therefore, there is a possibility of this reality changing.

As regards professional qualification, an increase in the number of specialist nurses in the country was noted. In this perspective, it is interesting to make a comparison between a multi-center study published in 1998 and another study published in 2011. The first study, ${ }^{9}$ had the participation of 237 nurses from 34 ICUs, and only 61 of the participants reported having a graduate degree, with the course being a specialization in medical-surgical nursing or in another area, other than intensive care. In the period of analysis, the authors found that the proportion of specialists in the ICU was relatively low and can be directly related to being a highly specialized unit, which could be a limiting factor if the professional wanted to act in parallel or subsequently in another area of care. In the second study ${ }^{10}$ data were collected from 263 nurses active in the ICU and revealed that $74 \%$ of them had at least one graduate course, with an increase in the prevalence of graduate Lato Sensu courses in intensive care nursing, a characteristic that is being seen increasingly earlier in these nurses. ${ }^{10}$ In this perspective, the analysis found that the nursing care in intensive care sectors requires an ability to handle complex situations with speed and accuracy, i.e., the current demand requires competence in integrating information, building judgments and establishing priorities. $^{10}$

The complex situations that require decision making in ICUs demand that a nurse be prepared to face ethical and technical problems. It is therefore the responsibility of nurses to prevent, detect and act, for instance, during complications, immediately and effectively. The responsibility of caring is the order of the day, which in turn reflects on 
some of the ways of being and performing nursing in intensive care. ${ }^{11}$ Nurses also need to specialize to acquire these skills.

Regarding the number of jobs, the results of this study indicate that there is no significant difference, i.e., $53 \%$ have one job and $47 \%$ of nurses have more than one job. Moreover, $58 \%$ of the professionals work in a public sector hiring scheme. The data collected should be considered for comparison in the research to take effect $a$ posteriori, precisely to assess the impact of current claims that discuss both the regulation of working hours, aiming at conditions for safe practice, and the acquisition of better wage conditions, making the professional choose for exclusive dedication.

This point is emphasized in a study that affirms that professionals often do double shifts and overtime to ensure their standard of living and livelihood of their family. ${ }^{12}$ The health of this worker is constantly bombarded by financial concerns that afflict human beings, exposing their health to risks of various natures, keeping them away from family and social life, being susceptible to stress and irritability. This situation leads us to a crucial question, whether the remuneration in nursing was adequate and befitting the importance of the profession, possibly not obliging professionals to face several days of work to improve their income and not sacrifice their time, certainly enabling them some free time to care for themselves.

In this context of discussion, the skills indicated by the study participants precisely seem to be a necessary condition for the performance in intensive care. Therefore, incorporating theoretical and scientific reasoning, leadership skills, insight, initiative, teaching ability, maturity and emotional stability are essential for the performance of ICU nurses. Faced with this demand for knowledge, these professionals need constant updating, as they must be prepared to face emerging complications. ${ }^{13-14}$

The act of leadership in a critical care unit differs from other units due to the challenge to integrate the complex care of patients who are critically ill and at risk into a safe, harmonious and scientific environment, not only grounded in objectivity, but also in subjectivity, in which the individual under care is the center of attention, in order to maintain life, also being a person who has fears and emotions. ${ }^{14}$

Nurses bring, in their essence, contact with others, either by exercising the art of care, as well as managing teams and worrying for those they care for, that is, since they resolve conflicts, prac- tice fairness in decision making, guide by the law of ethics and professional practice, guide new behaviors, seek the participation of their peers in building plans and projects, thus, the nurse will be a leader and not the boss. ${ }^{15}$

In a survey about nurses from different educational institutions, managing nurses were asked about the hiring of new graduates to work in ICUs. Among the nine people interviewed, four of them reported that they hired professionals only after three months of training, and not assuming critical areas. ${ }^{6}$ The others justified and indicated that they preferred more experienced nurses and not just those with theoretical knowledge.

Competence can be seen as the knowledge and skills that are required to perform the work. This implies a clear understanding of the work and, therefore, competence is equivalent to how professionals understand what is being done, and the context of their job, i.e., it is important to value the subject, their work environment and the specifics of both. ${ }^{16}$

Nursing education is permeated by various abilities and skills, which are being built throughout the academic learning process. Reflecting on how to develop the teaching and learning of leadership is essential for the training of nurses with this skill.

In turn, the research participants, upon recognizing the high complexity of the critically ill patient and in an atmosphere filled with technology as a motivating factor when working in intensive care, recognize the singularity of the profile of this nurse. In this respect, even though technology generally impacts on people, in the health area, this impact is evidenced in daily work, especially in the intensive care scenario where curiosity and fascination produce approximations thereto by the nurse. Thus, this professional needs to present multiple facets, in order to be able to meet the needs of the performance required by this different type of care, which requires different dialogs with various sorts of knowledge. It is an area of care that requires from nurses a proactive and autonomous attitude, that is, they must demonstrate interest and willingness in the continuous search for knowledge, so it can be later applied in the care of the patient. ${ }^{17}$

In a survey conducted in ICUs of two hospitals in southern Brazil, the existence of potential factors for employee satisfaction and consequent health of the worker were observed. Among these factors are the feeling of gratification and 
recognition of their work, as well as feeling useful and needed by patients and their families. In this context, autonomy is also a motivational aspect for the professional nurse. ${ }^{18}$

Finally, the lack of specific educational programs for professionals in intensive care was reported, along with the lack of time for qualification out of service. It is known that for continuing education programs to be conducted efficiently, human, material, financial and physical resources are also needed, in an adequate and affordable way. It is also essential that the institution provides the minimum conditions of employment, so that the professionals involved with continuing education develop their activities in an efficient and continuous manner. Therefore, it becomes necessary that both the management and the head nurse provide basic essential conditions to the development of these activities, such as availability and compatibility of working hours, and the adoption of strategic mechanisms to encourage the participation of professionals involved in continuing education.

Continuous education happens through programs that meet the learning needs of nurses, as well as in relation to the efficient use of advanced technology, contributing to familiarize nurses with the technological equipment used in hospitals. It consists of a formal resource, although informal education, in turn, also constitutes a way for nurses to update the technological changes and advances, as the exchange of experiences among colleagues and reading of published papers are strategies outlined to further knowledge on the subject.

Moreover, continuous education is conceptualized as a set of experiences subsequent to the initial training, allowing the worker to maintain, increase or improve their competence, so that it is compatible with the development of their responsibilities, thus characterizing competence as an individual attribute. ${ }^{19}$

A survey on technological advances applied to nursing care, which included 43 hospital institutions, revealed that, in relation to the initial training to work in the ICU, $79 \%$ of the institutions reported having a specific program in this area and $20 \%$ did not. In relation to programs for updating, $41 \%$ of institutions performed them periodically or occasionally, whereas $58 \%$ did not offer this type of training. ${ }^{20}$

In this scope, the importance of in-service education for nursing stands out as a mainstay for effective patient care. In other words, an edu- cational process that is updated and coherent with the specific needs of the area, maintains its staff valued and capable of presenting a good professional performance. ${ }^{19}$

Tiredness and stress, and the need to maintain more than one job are also factors that hinder the development of activities and a better performance in the ICU. In this perspective, the tiredness and stress of nurses in intensive care deserve to be highlighted and must be contextualized because the ICU is a closed environment, with artificial lighting and accelerated routines, an environment where sophisticated and noisy equipment are used for the care of the patient, whose possibility of death is present at all times. Such conditions can directly affect the professional who takes care of the critical patient. ${ }^{21}$

Consequently, in this workplace, professionals may fail to develop their activities, thus compromising the quality of life of workers and a reduction in the effectiveness and efficiency of the activities performed by intensive care nurses. ${ }^{22-23}$

\section{FINAL CONSIDERATIONS}

In this study, the unveiling of professionals who seek scientific events focused on intensive care shows the existence of a characteristic profile of nurses in the environment studied, marked by the following elements: a predominance of women, a mean age of around 35 years, most with at least one graduate course in the Lato Sensu modality. Among the study participants, there is an appreciation of technical knowledge followed by scientific knowledge and leadership as essential skills in the intensive care nurse. These professionals seek working in intensive care due to the high technological complexity along with the art and fascination of caring for critical patients. It is known that there are health producing factors, such as fascination and desire to work in the intensive care unit. In contrast, there is, admittedly, an overload of work, which can be considered a stressful factor for the worker.

These specificities allow the assumption that there is a certain professional profile to work in the ICU. Inexperienced nurses have the theoretical knowledge, however, they do not have all of the necessary features to operate at this location, thus experiencing the inclusion in this context of care in a peculiar way, i.e., they still need to add technical skills, improving them, ideally through a process of professional integration, considering 
the continuous education and gradual complexity of the caring process in the ICU.

With increasing technological advances incorporated into the care of the patient, it becomes essential to take ownership of the knowledge articulated to the insertion of technologies in health. Thus, professional qualification happens with continuing education, with the goal of mastering the technological language and assisting comprehensively, so as to benefit both patient and professional, safely.

The professional competences identified provide elements to set out guidelines for ICU nurses and to boost the elaboration of strategies for the development of a skilled nursing practice. Moreover, the partnership with the Nursing Department at AMIB is another important factor in the study, in that the nursing events bring together nurses working in different ICUs. In other words, this is also why a sample of nurses from different regions in the country was considered in the study.

Finally, this suggests the development of a study to propose a comparison between the profile of member nurses participating in events in the field of intensive care, non-member nurses participating in events in the area and non-member and non-participating nurses of scientific events in the area of intensive care.

\section{REFERENCES}

1. Vargas MAO, Ramos FRS. Tecnobiomedicina: implicações naquilo e daquilo que a enfermagem faz em terapia intensiva. Texto Contexto Enferm. 2008 Jan-Mar; 17(1):168-76.

2. Fulbrook P. Developing best practice in critical care nursing: knowledge, evidence and practice. Nurs Crit Care. 2003 Mai-Jun; 8(3):96-102.

3. Nóbrega MFB, Matos MG, Silva LMS, Jorge MSB. Perfil gerencial de enfermeiros que atuam em um hospital público federal de ensino. Rev Enferm UERJ. 2008; 16(3):333-38.

4. Rabaglio MO. Gestão por competências: ferramentas para atração e captação de talentos humanos. Rio de Janeiro (RJ): Qualitymark; 2012.

5. Ministério da Saúde (BR), Conselho Nacional de Saúde, Comissão Nacional de Ética em Pesquisa. Resolução n. 196 de 10 de outubro de 1996: diretrizes e normas regulamentadoras de pesquisa envolvendo seres humanos. Brasília (DF): MS; 1996.

6. Guerrer FJL, Bianchi ERF. Caracterização do estresse nos enfermeiros de unidades de terapia intensiva. Rev Esc Enferm USP. 2008 Jun; 42(2):355-62.

7. Conselho Federal de Enfermagem [página na
Internet]. Brasília (DF): COFEN; 2011. [acesso 2012 Ago 10]. Disponível em: http://www. portalcofen.gov.br/sitenovo/sites/default/files/ pesquisaprofissionais.pdf

8. Brito AMR, Brito MJM, Gazzinelli MFC, Montenegro LC. Representações sociais de discentes de graduação em enfermagem sobre "ser enfermeiro". Rev Bras Enferm. 2011 Maio-Jun; 64(3):527-35.

9. Koizumi MS, Kimura M, Miyadahira AMK, Lopes DA, Cruz M, Padilha KG et al. Educação continuada da equipe de enfermagem nas UTIs do município de São Paulo. Rev Latino-Am Enferm [online]. 1998 [acesso 2013 Mai 29]; Jul; 6(3):33-41. Disponível em: http:/ / www.scielo.br/pdf/rlae/v6n3/13889.pdf

10. Silva RC, Ferreira MA. Características dos enfermeiros de uma unidade tecnológica: implicações para o cuidado de enfermagem. Rev Bras Enferm. 2011 Jan-Fev; 64(1):94-105.

11. Vargas MAO, Ramos FRS. Responsabilidade no cuidar: do tempo que nos toca viver como enfermeiros/as intensivistas. Rev Esc Enferm USP. 2011 Ago; 45(4):876-83.

12. Pires D, Lopes MGD, Silva MCN, Lorenzetti J, Peruzzo SA, Bresciani HR. Jornada de 30 horas semanais: condição necessária para assistência de enfermagem segura e de qualidade. Enfermagem em Foco. 2010; 1(3):114-18.

13. Baggio MA, Formaggio FM. Trabalho, cotidiano e o profissional de enfermagem: o significado do descuidado de si. Cogitare Enferm. 2008 Jan-Mar; 13(1):67-74.

14. Gelbeck FL, Sousa LA, Dal Sasso G, Nascimento E, Bub MBC. Liderança em ambientes de cuidados críticos: reflexões e desafios à enfermagem brasileira. Rev Bras Enferm. 2009 Jan-Fev; 62(1):136-9.

15. Balsanelli AP, Cunha ICKO. Liderança no contexto da enfermagem. Rev Esc Enferm. USP. 2006 Jan-Mar; 40(1):117-22.

16. Sporrong SK, B Arnetz B, Hansson MG, Westerholm P, Höglund AT. Developing ethical competence in health care organizations. Nurs Ethics. 2007 Nov; $14(6): 825-37$.

17. Silva RC, Ferreira MA. Representações sociais dos enfermeiros sobre a tecnologia no ambiente da terapia intensiva. Texto Contexto Enferm. 2009 JulSet; 18 (3):489-97.

18. Azambuja EP, Pires D, Vaz MRC, Marziale MH. É possível produzir saúde no trabalho da enfermagem? Texto Contexto Enferm. 2010 OutDez; 19(4):658-66.

19. Paschoal AS, Mantovani MF, Méier MJ. Percepção da educação permanente, continuada e em serviço para enfermeiros de um hospital de ensino. Rev Esc Enferm USP. 2007 Set; 41(3):478-84.

20. Silva RCL, Kaczmarkiewicz CC, Cunha JJSA, Meira IC, Figueiredo NMA, Porto IS. O significado da 
tecnologia no pós-operatório imediato de cirurgia cardíaca. Rev SOCERJ. 2009 Jul-Ago; 22(4):210-18.

21. Cavalheiro AM, Moura Junior DF, Lopes AC. Stress in nurses working in intensive care units. Rev Latino-Am Enferm. 2008 Jan-Fev; 16(1):29-35.

22. Jira, Moraes EL, Pereira EA, Reimão RNAA. Evaluation of the sleep pattern of nursing professionals working night shifts at the intensive care units. Einstein. 2008 Jul-Set; 6(3):296-301.

23. Versa GLGS, Murassaki ACY, Inoue KC, Melo WA, Faller JW, Matsuda LM. Estresse ocupacional: avaliação de enfermeiros intensivistas que atuam no período noturno. Rev Gaúcha Enferm. 2012 Jun; 33(2):78-85. 